International Research Journal of Engineering, IT \& Scientific Research
Available online at https://ijcujournals.us/journals/index.php/irjeis
Vol. 5 No. 1, January 2019, pages: 9 14
ISSN: 2454-2261
https://doi.org/10.21744/irjeis.v5n1.462

\title{
Pathogenic Bacteria Contamination of Loin of Bali Cattle Slaughtered at Modern and Traditional Abattoirs
}

\begin{tabular}{|c|c|}
\hline & $\begin{array}{r}\text { Ni Luh Putu Sriyani }{ }^{\mathrm{a}} \\
\text { Ni Made Artiningsih Rasna }{ }^{\mathrm{b}} \\
\text { Anak Agung Oka }^{\mathrm{c}} \\
\text { I Nyoman Tirta Ariana } \\
{ }^{\mathrm{d}} \\
\text { Sri Anggreni Lindawati } \\
\text { Wayan Sayang Yupardi }\end{array}$ \\
\hline Article history: & Abstract \\
\hline $\begin{array}{l}\text { Received: } 18 \text { July } 2018 \\
\text { Accepted: } 30 \text { November } 2018 \\
\text { Published: } 11 \text { December } 2018\end{array}$ & $\begin{array}{l}\text { The aim of this study was to observe the contamination of pathogenic } \\
\text { bacteria on the loin of the Bali cattle at abattoirs with modern cutting systems } \\
\text { and traditional one. The loin samples were taken at modern abattoirs of } \\
\text { Mambal which is managed by the Office of the Livestock Marine District of } \\
\text { Badung. Loin sample that cutting traditional slaughter system was taken at } \\
\text { Mambal village. The loins were taken into the laboratory of "Teknologi Hasil }\end{array}$ \\
\hline $\begin{array}{l}\text { Keywords: } \\
\text { Bali cattle beef; } \\
\text { Bali cattle slaughtered; } \\
\text { modern and traditional } \\
\text { abattoirs; } \\
\text { pathogenic bacteria } \\
\text { contamination; } \\
\text { pathogenic bacteria; }\end{array}$ & $\begin{array}{l}\text { Ternak dan Mikrobiologi", Faculty of Animal Science Udayana University to } \\
\text { test their pathogen bacteria content. The design used in this study was } \\
\text { completely randomized design }(C R D) \text {. Data obtained were analyzed with } \\
\text { Two Independent Sample test (T-Test). The results showed that the total } \\
\text { microbial content of TPC (Total Plate Count) on the loins cutting at modern } \\
\text { abattoir were } 1.2 \times 10^{5} \text { and they were higher significantly different }(\mathrm{P}<0.05) \\
\text { than the loins at the traditional abattoir } 7.6 \times 10^{4} \text {. The content of coliform } \\
\text { bacteria for } 3.93 \times 10^{3} \text { indicate the results of the loin of the Bali cattle which } \\
\text { was slaughtered in a modern abattoir, were significantly lower }(\mathrm{P}<0.05) \\
\text { than at the traditional one }\left(3.28 \times 10^{4}\right) \text {. They were no contaminations with } \\
\text { Escherichia coli on both loins of the Bali cattle modern or traditional } \\
\text { abattoirs. From the data mentioned above, it can be concluded that the } \\
\text { content of both TPC loin was still below the SNI threshold (SNI } 7388,2009) \text {. } \\
\text { But pathogenic bacteria coliform content of the loin of the Bali cattle at } \\
\text { traditional abattoirs was more polluted than the modern one. Even though } \\
\text { both of them were still upper than the threshold of SNI (Standar Nasional } \\
\text { Indonesia). }\end{array}$ \\
\hline
\end{tabular}

2454-2261 ${ }^{\odot}$ Copyright 2019. The Author. Published by SLOAP. This is an open-access article under the CC-BY-SA license (https://creativecommons.org/licenses/by/4.0/) All rights reserved.

${ }^{a}$ Universitas Udayana, Faculty of Animal Husbandry, Denpasar, Indonesia

${ }^{\mathrm{b}}$ Universitas Udayana, Faculty of Animal Husbandry, Denpasar, Indonesia

${ }^{c}$ Universitas Udayana, Faculty of Animal Husbandry, Denpasar, Indonesia

${ }^{d}$ Universitas Udayana, Faculty of Animal Husbandry, Denpasar, Indonesia

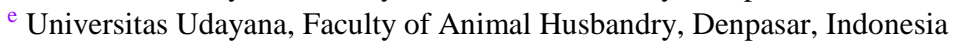

${ }^{\mathrm{f}}$ Universitas Udayana, Faculty of Animal Husbandry, Denpasar, Indonesia 


\author{
Author correspondence: \\ Sriyani, NLP \\ Universitas Udayana, Faculty of Animal Husbandry, Denpasar, Indonesia \\ Jl. PB. Sudirman, Denpasar Bali, Indonesia \\ Email address: sriyaninlp@unud.ac.id
}

\title{
1. Introduction
}

The direction policy of the Director General of Animal Husbandry and Animal Health after 2015, it seems has to change strategy from self-sufficiency strategies approach into national food needs. It's not only in quantity but also the fulfillment of compliance quality. Partama et al., (2018), meat is one of the foods that has been paying more attention to its quantity and quality by the government. To fulfill the national beef demand the Government of Indonesia imports and also uses domestic beef production by utilizing the beef cut in various abattoirs. They are operated in the society with two systems, are a modern and traditional one. Miwada et al., (2018), the modern cutting system follows is the procedures of national standards of slaughter i.e. animals are stunned first and do the slaughtering, carcasses with hanging. But the traditional one is not stunned before slaughter, carcasses are carried out on the floor and without the aging process. Both of those cutting systems is expected to result in differences quality of microbiological contamination especially pathogenic bacteria on the beef are produced. Referring to the above problems they need scientific information about the comparative test of pathogenic bacterial contamination of beef which is cut with modern and traditional cutting.

\section{Materials and Methods}

\section{Research material}

The study or research beef samples were taken from the "longissimus dorsi" muscle at the modern cutting system abattoirs of Mambal and the traditional one taken at traditional abattoirs. The samples were brought into the Laboratory of "Teknologi Hasil Ternak dan Mikrobiologi" Udayana University for test microbiological quality of the muscles loin.

\section{Methods}

Random sampling was conducted in this research to a number of livestock owners who did the cutting at the modern and traditional abattoirs.

\section{TPC test}

Total plate count (TPC) is a technique to calculate the total number of microbes found in beef by using media PCA (Plate Count Agar) for analyzing the TPC of the beef in the following manner, i.e 10 grams of beef inserted into the Erlenmeyer tube which already contain for $90 \mathrm{ml}$ solution of sterile peptone water $0.1 \%$, to obtain a dilution of $10^{1}$. This dilution was homogenized and diluted again by pipetting $1 \mathrm{ml}$ of it then inserted into a test tube which already contains $9 \mathrm{ml}$ peptone dilution then it dilution become $10^{2}$, and so on until its dilution up to $10^{6}$. Then saw method is conducted (Jenie \& Fardiaz, 1989). It is done in a sterile room and adjacent to the Bunsen flame. The aim of it is to avoid contamination with the extrinsic environment, by taking the dilution rate of $10^{5}, 10^{6}$ and $10^{7}$ with a pipette in which each of them pours with PCA media (temperature is about $45^{\circ} \mathrm{C}$ ) into a petri dish of $20 \mathrm{ml}$ and then close it again. Furthermore, it is homogenized by shaking it carefully to allow it to become a solid media. A sow is made twice (Duplo) the insert them into an incubator at a temperature of $37^{\circ} \mathrm{C}$ in a state upside down, and the results can be calculated within 24-48 hours.

\section{Coliform and Escherichia coli test}

The method used to obtain a total of Escherichia coli and coliform bacteria is spread method (Jenie \& Fardiaz, 1989) using the media EMBA i.e 5 grams of beef put into the Erlenmeyer flask that had contained peptone water solution $0.1 \%$ with a volume of $45 \mathrm{ml}$, so it gets a $10^{1}$ dilution. Then dilution is homogenized and diluted again by 
taking $1 \mathrm{ml}$ with a pipette and put it into a test tube which already contains $9 \mathrm{ml}$ peptone thus dilution obtained for $10^{2}$ and $10^{3}$. The dilution has taken by a sterile pipette for $0.1 \mathrm{ml}$ and then poured on a surface that has a solid EMBA media in Petri dishes and incubated at a temperature of $37^{\circ} \mathrm{C}$ in a state upside down, and the results can be calculated after 24-48 hours. The plantations are done at the level of dilution of $10^{1}, 10^{2}$ and $10^{3}$ for counting bacterial colonies growing with methods cup count by choosing the number of colonies growing in a petri dish ranges between 30-300 colonies (Jenie \& Fardiaz, 1989). It formula is: colonies / gram = Number of colonies petri dish $\mathrm{x} 1$ / dilution factor.

Statistic Analysis

Data obtained were analyzed with T-test on (Two Independent Sample) Steel and Torrie 1989, by using SPSS 16. Microbial data which were obtained previously they have to be transformed into $\log \mathrm{x}$ formed.

\section{Results and Discussions}

Here is the research data regarding microbial contamination (TPC, Coliform, Escherichia coli) on the loin of the Bali cattle cut with T1 and T2, modern and traditional systems respectively (Table 1)

Table 1

Profile of microbial of the loin of the Bali cattle which are slaughtered in modern (T1) and traditional abattoirs (T2)

\begin{tabular}{lllll}
\hline \multirow{2}{*}{ Variables } & \multicolumn{2}{c}{ Treatmens } & \multirow{2}{*}{ (SNI) } & \multirow{2}{*}{ SEM } \\
\cline { 2 - 3 } & $\mathrm{T}_{1}$ & $\mathrm{~T}_{2}$ & \\
\hline TPC $(\mathrm{cfu} / \mathrm{g})$ & $1,2 \times 10^{5 \mathrm{a}}$ & $7,6 \times 10^{4 \mathrm{~b}^{*}}$ & $1 \times 10^{6}$ & \\
\hline Coliform $(\mathrm{cfu} / \mathrm{g})$ & $3,9 \times 10^{3 \mathrm{~b}}$ & $3,3 \times 10^{4 \mathrm{a}}$ & $1 \times 10^{2}$ & \\
\hline E.coli $(\mathrm{cfu} / \mathrm{g})$ & negatif & negatif & $1 \times 10^{1}$ & \\
\hline
\end{tabular}

Information:

T1: loin muscle of the Bali cattle slaughtered at modern abattoirs

T1: loin muscle of the Bali cattle slaughtered at traditional abattoirs

Figures with different superscripts in the same row are significantly different $(\mathrm{P}<0.05)$

Based on the results of statistical analysis showed that the loin muscle of the Bali cattle slaughtered in modern abattoir (T1) generating total microbial / TPC for $1.2 \times 10^{5} \mathrm{cfu} / \mathrm{g}$, significantly different $(\mathrm{P}<0.05)$ higher than the loin of the Bali cattle slaughtered in the traditional abattoir (T2) was $7.6 \times 10^{4} \mathrm{cfu} / \mathrm{g}$. Total coliform bacteria in the loin of the Bali cattle slaughtered in modern abattoirs (T1) were of $3.9 \times 10^{3} \mathrm{cfu} / \mathrm{g}$ was statistically significantly different lower $(\mathrm{P}<0.05)$ than the loin of the Bali cattle slaughtered in the traditional slaughter abattoirs $(\mathrm{T} 2)$ i.e $3.3 \mathrm{x}$ $10^{4} \mathrm{cfu} / \mathrm{g}$. The Bali cattle loin of the cattle slaughtered in a modern abattoir (T1) has no Escherichia coli bacteria, as well as the loin of the Bali cattle slaughtered in the traditional abattoirs (Table 1).

\section{Discussion}

The aim of the evaluation of meat microbiology was to know the profile of pathogens microbial associated with sanitation and safety of food (Soeparno, 2009). Total plate count (TPC) on the meat needs to be known, to trust that the food is safe and to determine the total coliform and Escherichia coli in order to determine that sanitary of food or meat are indeed. Statistical analysis showed that the loin of the Bali cattle slaughtered in modern abattoirs (T1) was found that total microbial (TPC) on it was of $1.2 \times 10^{5} \mathrm{cfu} / \mathrm{g}$, and this was higher significantly different $(\mathrm{P}<0.05)$ than the loin of the Bali cattle slaughtered in traditional abattoirs (T2) i.e $7.6 \times 10^{4} \mathrm{cfu} / \mathrm{g}$. Even though, the results of this research showed that the TPC of the loin of the Bali cattle (Ti) and (T2) both are still below the threshold of safe food. They are 1 x $10^{6} \mathrm{cfu} / \mathrm{g}$ (SNI 7388, 2009).

Normally coliform bacteria habitation is in the intestines of humans and animals. The coliform bacteria are indicators of the presence of other pathogenic bacteria. More precisely, it is an indicator of bacterial contamination from pathogenic bacteria. The determination of Coliform is an indicator of pollution due to the number of colonies in

Sriyani, N. L. P., Rasna, N. M. A., Oka, A. A., Ariana, I. N. T., Lindawati, S. A., \& Yupardi, W. S. (2018). Pathogenic bacteria contamination of loin of Bali cattle slaughtered at modern and traditional abattoirs. International Research Journal of Engineering, IT and Scientific Research, 5(1), 9-14. https://doi.org/10.21744/irjeis.v5n1.462 
which positively correlated with the presence of pathogenic bacteria (Jay, 1992). Total coliform bacteria in the loin of Bali cattle slaughtered in a modern abattoir (T1) were $3.9 \times 10^{3} \mathrm{cfu} / \mathrm{g}$. Statistically, it shows significantly different lower $(\mathrm{P}<0.05)$ than the loin of the Bali cattle in the traditional abattoirs (T2) i.e $3.3 \times 10^{4} \mathrm{cfu} / \mathrm{g}$. This was suspected due to the population of total coliform bacteria in the microbial loin of the Bali cattle slaughtered in a modern abattoir was lower than the loin of the Bali cattle in traditional abattoirs. It may be due to the viscera expanses process better at modern abattoirs. In modern abattoirs carcass executed by hanging it and the viscera was kept in viscera room immediately. So that carcass and rumen content contamination while the floor can be minimized. But the content of coliform of the loin of the Bali cattle slaughtered in modern abattoirs is above the set threshold of $1 \mathrm{x}$ $10^{2} \mathrm{cfu} / \mathrm{g}$ (SNI 7388, 2009). This may occur from other sources of contamination such as a cutter, workers who did not set sanitary standards including glove mask and others. Lunar et al., (1996) said that all things are direct contact with the meat, such as desks, equipment, vendee and environment could become a source of contamination. The cutting process is not found yet the source of contamination of coliform bacteria on the loin of the Bali cattle either slaughtered in modern (T1) or traditional (T2) abattoirs exceeded a set threshold of $1 \times 10^{2} \mathrm{cfu} / \mathrm{g}$ (SNI 7388, 2009).

Counting the number of Escherichia coli in meat is very important because the presentation of these microorganisms can be used as an assessment of the sanitary quality of meat and water (Suwan et al., 2003), and it shows that the foodstuffs are ever polluted by human sewage or animal, resulting in food microbiology Escherichia coli called sanitation indicators (Supardi \& Sukamto, 1999). Escherichia coli is one group of coliform bacteria (Jay, 1992). Type of Escherichia, Enterobacter, and Klebsiella bacteria called coliform group. Escherichia type has only one species, namely, Escherichia coli called fecal coliform, as found in the intestinal tract of animals or humans, so it is often used as an indicator of fecal contamination. The results of this research are not found Escherichia coli bacteria both in the loin of Bali cattle slaughtered in a modern and the traditional abattoirs. This phenomenon illustrates that the Coliform bacteria that contaminate the flesh is not the type of Escherichia coli. Another possibility contaminate the loin is the types of coliform bacteria such as Enterobacter, and Klebsiella but, in this research have not yet identified the two types of bacteria (Sriyani et al., 2018).

\section{Conclusion}

Based on the results of this study it can be concluded that the contamination of pathogenic bacteria, especially coliform bacteria of the loin the Bali cattle slaughtered in a modern abattoir was lower than the loin of the Bali cattle in traditional abattoirs. The content of the Escherichia coli of the loin of the Bali cattle slaughtered in both modern and the traditional abattoirs was negative. The content of both TPC on the loin samples of the Bali cattle was still below a defined threshold (SNI 7388, 2009), but the content of Coliform bacteria in both samples of the Bali cattle was above of the threshold (SNI 7388, 2009) on carcass quality and beef.

\section{Conflict of interest statement and funding sources}

The authors declared that they have no competing interest. The study was financed by the Authors.

\section{Statement of authorship}

The authors have a responsibility for the conception and design of the study. The authors have approved the final article.

\section{Acknowledgments}

The authors thank the head and staff of the Mambal abattoirs and the Laboratory of Animal Products and Microbiology, Faculty of Animal Science, Universitas Udayana for their cooperation during the research period. 


\section{References}

Fardiaz, S., \& Jenie, B. S. L. (1989). Uji sanitasi dalam industri pangan. PAU Pangan dan Gizi, IPB, Bogor.

Jay, J. M. (1992). Microbiological food safety. Critical Reviews in Food Science \& Nutrition, 31(3), $177-190$.

Jenie, B. S. L., \& Fardiaz, S. (1989). Uji Sanitasi dalam Industri Pangan: Petunjuk Laboratorium. Bogor: PAU Pangan dan Gizi.

Lunar, L., Sicilia, D., Rubio, S., Pérez-Bendito, D., \& Nickel, U. (2000). Degradation of photographic developers by Fenton's reagent: condition optimization and kinetics for metol oxidation. Water Research, 34(6), 1791-1802. https://doi.org/10.1016/S0043-1354(99)00339-5

Miwada, I. N. S., Sumadi, I. K., Wrasiati, L. P., \& Sutama, I. N. S. (2018). Gelatin characteristics of Bali cattle skin protein extract on acetic acid concentration and different length of curing. International Journal of Life Sciences, 2(2), 12-21. https://doi.org/10.29332/ijls.v2n2.119

Nasional, B. S. (2009). Batas Maksimum Cemaran Mikroba dalam Pangan: Standar Nasional Indonesia (SNI) 7388.

Partama, I. B. G., Yadnya, T. G. B., Trisnadewi, A. A. A. S., \& Sukada, I. K. (2018). Increasing nutrition value of fermented rice hull through biofermentation of lactobacillus complex bacteria supplemented. International Journal of Life Sciences, 2(2), 73-82. https://doi.org/10.29332/ij1s.v2n2.179

Soeparno. (2009). Meat Science and Technology. Gadjah Mada University Press. Yogyakarta.

Sriyani, N., Siti, W., Suarta, G., Partama, I. B. G., Ariana, N. T., \& Yupardhi, W. S. (2018). Responses of corncob as replacement of elephant grass on performance and carcass profile of Bali cattle. International Journal of Life Sciences, 2(1), 42-49. https://doi.org/10.29332/ijls.v2n1.93

Supardi, I., \& Sukamto, M. (1999). Mikrobiologi dalam Pengolahan dan Keamanan Pangan. Penerbit Alumni. Bandung, 290.

Suwansonthichai, S., \& Rengpipat, S. (2003). Enumeration of coliforms and Escherichia coli in frozen black tiger shrimp Penaeus monodon by conventional and rapid methods. International journal of food microbiology, 81(2), 113-121. https://doi.org/10.1016/S0168-1605(02)00190-3

Sriyani, N. L. P., Rasna, N. M. A., Oka, A. A., Ariana, I. N. T., Lindawati, S. A., \& Yupardi, W. S. (2018). Pathogenic bacteria contamination of loin of Bali cattle slaughtered at modern and traditional abattoirs. International Research Journal of Engineering, IT and Scientific Research, 5(1), 9-14. https://doi.org/10.21744/irjeis.v5n1.462 


\section{Biography of Authors}

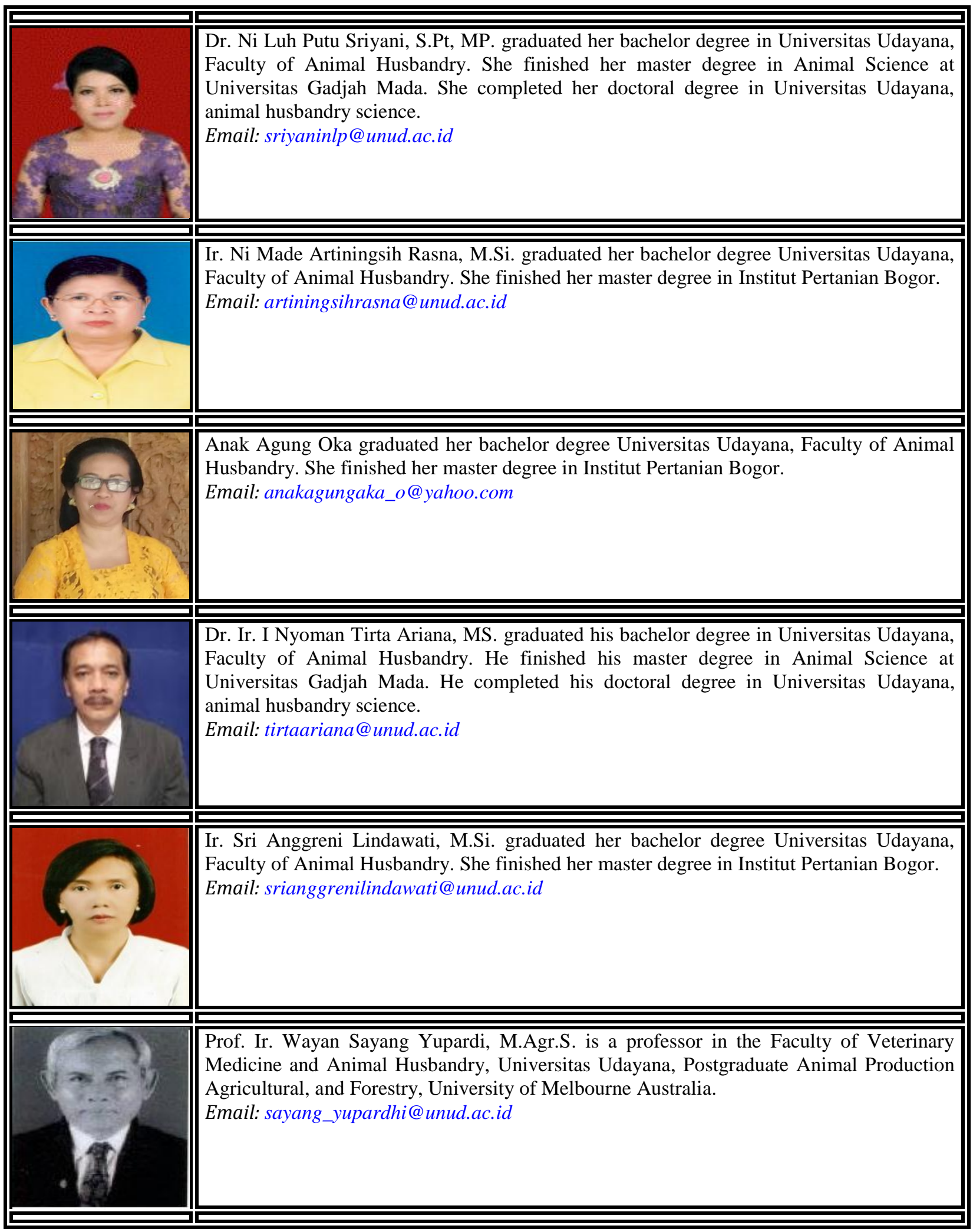

